Використання активованих амарантовою олією дріжджів дозволяє покращити окремі органолептичні показники хліба. Оптимізовано дозу амарантової олії, та розроблено рецептуру хліба з пшеничного борошна.

Ключові слова: дріжджі, бродіння, кислотність, рослинні олії, амарант, сквален, поживне середовищее, активація.

\title{
ЛIТЕРАТУРА
}

1. Капрельяни Л. В. Мікробіологія харчових виробництв [Текст] / Л. В. Капрельяни, Л. М. Пилипенко, А. В. Сгорова та ін. // Херсон: ФОП Гринь Д.С., 2016. - 476 с.

2. Дробот В. І. Технологія хлібопекарського виробництва [Текст] / В. І. Дробот // К.: Логос, 2002. - 365 c.

3. Шендеров Б. А. Медицинская микробная экология и функциональное питание [Текст] / Б. А. Шендеров // Том III : Пробиотики и функииональное питание. - М. : Изд-во ГРАНТЬ, 2001. - 288 c.

4. Крюк Т. В. Сучасні методи експертизи харчових олій [Текст] / Т. В. Крюк, Р. С. Транковська // Наук. журнал ЛОГОS. «Мистеитво наук. думки». - Вип. 2, лютий 2019, - C. 46-49.

5. Чиркова Т. В. Амарант - культура ХХІ века [Текст] / Т. В. Чиркова // СОЖ, 1999. - № 10.- C. 22-27.

6. Chulak L. D. Ultrasonic estraction of amarant oils [Text] / L. D. Chulak, V. G. Zadorozhny, Yu. L. Chulak, O. L. Chulak, O.V. Tatarina // Journal of Education, Health and Sport. 2018: 8 (8): 1223-1232. DOI: 10.5281/zenodo.1465021

7. Килименчук Е. А. Биотехнологические аспекты получения кисломолочного продукта функиионального назначения [Текст] // Е. А. Килименчук, М. И. Охотская, Г. И. Евдокимова // Харчова наука і технологія, 2015. - № 3. - T. 9. C. 14-18. DOI: $10.15673 / 2073-8684.3 / 2015.50274$

8. Килименчук О. О. Застосування олї̈ амаранту при вирощуванні Lactobacillus plantarum [Текст] / O. О. Килименчук, М. І. Охотська, Г. Й. Євдокимова // Наук. пр. ОНАХТ, 2015. - Вип. $48 . \quad$ С. $88-93$. DOI:10.15673/swonaft.v0i48.793

9. Килименчук О. О. Методичні вказівки до виконання лабораторних робіт з дисиипліни «Технічна мікробіологія. Частина 2 (спечкурс)» для студентів спеціальності 181 «Харчові технології та інженерія» освітньої програми підготовки «Технологічна експертиза та безпека харчової продукції» денної та заочної форм навчання / Уклад.: О. О. Килименчук, А. В. Сгорова, Л. В. Труфкаті, Н. О. Швеиь. - Одеса: ОНАХТ, 2016. - 71 с.с.

Надійшла 22.03.2019. Рецензія 15.04.2019.

До друку 07.06.2019.

Адреса для переписки:

112 Kanatna Str., 65039 Odesa, Ukraine,

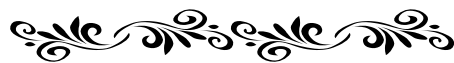
kylymenchuk@gmail.com

UDC [639.3.043:639.211]-021.4

L. FIHURSKA, PhD, Associate Professor, Department of Feed and Biofuel Technologies V. THORENKO, Master degree student, Department of grain technology and grain business Odessa National Academy of Food Technologies, Odessa (Ukraine)

\section{THE CHARACTERISTIC OF COMPOUND FEEDS FOR TILAPIA FISH}

\begin{abstract}
The article states that, according to the literature review, in aquaculture of freshwater fish species that acquire everincreasing production volumes, tilapia is leading with $17 \%$, and it is follower by carp (15\% of world volume). For almost 60 years, tilapia have moved into second place in the global fish production, with the prospect of taking first place in the next 2-3 years and overtake carp in world production. Since fish is a rich source of proteins and essential amino acids, vitamins, polyunsaturated fatty acids, macro and micronutrients, it is also an important component of the diet of the population. Meat of tilapia is dense, non-fat, protein content close to trout meat, does not contain intermuscular bones. One of the priorities of the development of fish farming in Ukraine is the cultivation of tilapia. The amount of feed consumption in the world is increasing every year, due to the rapid growth in demand for tilapia. Currently, Ukrainian businessmen are interested in the production of catfish and tilapia. The most famous aquapride plants that grow these breeding objects are Lauren Aquaculture LLC (Rivne region), Aqua System Organic LLC (Kiev region), Catfish from Pavlysh TM (Kirovograd region), TM "First City Fish Farm 'I want a catfish "(Kiev). That is why the production of balanced domestic feed for tilapia is an important task of the feed industry of Ukraine. The theoretical study was devoted to the issue of tilapia feed production. The nutritional value of feed for tilapia depends on the stage of the life cycle of this species of fish. It was shown the world leading manufacturers of feed for tilapia, it was analyzed the nutritional value of feed for this species of fish on the content of crude protein in the starting, growth and finishing periods, respectively. The requirements for the content of essential nutrients, essential amino acids, minerals (micro and micronutrients), water-and fat-soluble vitamins and restrictions on the content of crude fiber are given. The programs of feeding of tilapia of various producers are analyzed and an own program of feeding this species of fish is developed, it is divided the starting, growth and finishing period of tilapia growing. For starter mixed feeds for tilapia, the content of crude protein should be at least $45 \%$, crude fat at least $12 \%$, crude fiber not more than $1.5 \%$, gross energy not less than $18 \mathrm{MJ}$, crude ash not more than $8 \%$. For grower's feeds, the content of crude protein should be at least $40 \%$, crude fat at least $12 \%$, crude fiber not more than 3\%, gross energy not less than $17 \mathrm{MJ}$, crude ash not more than $9.5 \%$. For finishing feeds, the content of crude protein should be at least $30 \%$, crude fat at least $6 \%$, crude fiber not more than $5 \%$, gross energy not less than 17 MJ, crude ash not more than 7\%. Amino acids requirements are very important for tilapia fish, feeds for tilapia from any period should contain lysine should be at least $1.6 \%$, methionine should be at least $0.7 \%$.
\end{abstract}

Key words: compound feed for tilapia fish, feed manufacture technology for tilapia fish feeds, nutritional requirements for tilapia fish feeds. 


\section{Introduction}

Tacon A. (2008) notes that in freshwater aquaculture, the main fish species that are gaining evergrowing production are tilapia - $17 \%$ and carp fish - $15 \%$ [1]. Industrial cultivation of tilapia, as an object of fish farming, has begun in 1957. During the 60s of 20 century the total annual production of tilapia was less than 100 tons, now this figure exceeds 14 million tons per year. The production of farmed tilapia has witness a 6-fold increase during the past 15 years, jumping from 383,654 $\mathrm{mt}$ in 1990 to 2,096,187 $\mathrm{mt}$ in 2005 (FAO, 2007 [3]). For nearly 60 years, tilapia has moved into 2 nd place in the world fish production, with the prospect of taking the first place in the next 2-3 years and overtaking carp in terms of the global production [1].

According to the WorldFish Center and the University of Guelph, the volume of feed consumption in the world is growing every year, which is associated with a rapid increase in demand for tilapia (Fig. 1). And as a result, the breeding of this fish in any corner of the world through a fairly rapid growth of individuals to the presentation, a rapid increase in their numbers and a fairly good ability to adapt to the conditions of the environment in which Tilapia is grown. However, there are not so many manufacturers of feed for feeding tilapia in the world. Among them, the most famous manufacturers of feed products such as: Cargill, Purina, Biomar, Coppens [1-3].

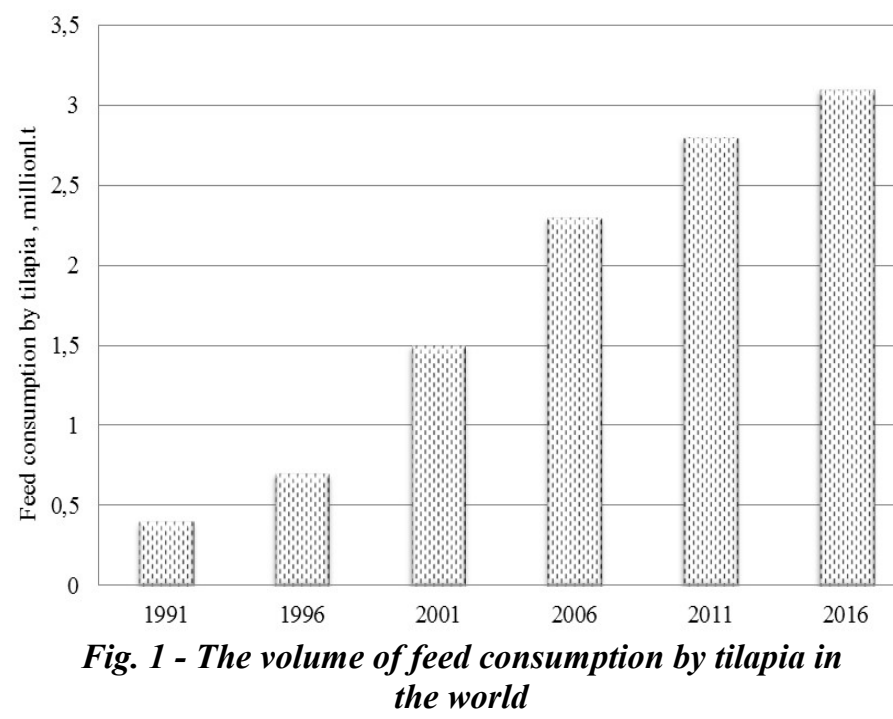

\section{Purpose and objectives of the analysis}

The purpose of the study is to gather information about the requirements of tilapia fish in crude protein, amino acids, crude fat, crude ash, fiber, some minerals, water and fat soluble vitamins etc. in order to analyze the feeding program of tilapia fish of the different foreign producers, consequently to develop the own feeding program of tilapia fish, which is based on literature data and analyzes of it.

\section{Analysis of the literature data}

Currently, Ukrainian businessmen are interested in the production of catfish and tilapia. The most famous aqua plants that grow these breeding objects are LLC «Lauren Aquaculture» (Rivne region), LLC «Aqua System Organic» (Kiev region), brand name «Catfish from Pavlysh» (Kirovograd region), brand name «First City
Fish Farm», «I want a catfish» (Kiev). In the Kiev region launched a unique fish farm with tilapia, it is experimental development of Ukrainian production. Its author has created a system that allows in artificially created conditions to grow fish on an industrial scale. So far, there is only one pool on this farm. One of the main advantages is the size of aqua farms. Its area is only 120 square meters. Innovators have already set themselves the task - one thousand tons of fish in two years. To do this, Ukraine must have at least 20 such farms (Portal businessforecast).

Tilapia belongs to a large cyclic family. More than 70 species of tilapia genus belong to 4 genera: Oreochromis, Sarotherodon, Tilapia and Danakilia. For industrial fish farming, tilapia of the genus Oreochromis has the greatest interest. Tilapia niloticus (Oreochromis niloticus L.), Tilapia Aure or blue (Oreochromis aureus Steindacher), Tilapia macrochir (Oreochromis macrochir Boulenger) and others are valuable objects of an intensive fish farming [4]. The natural habitat of tilapia is considered to be the reservoirs of East Africa, it is found in the rivers Nile, Niger, Volta, Gambia; in the basin of Lake Chad; lakes: Albert, Edward, Rudolph, Bering, Tanganyika, in the west of Africa - in Senegal. Tilapia has a high plasticity in relation to environmental factors. In the natural range is found in both fresh and salt waters.

These fish have a number of valuable qualities that allow them to grow in specific conditions of detention. They have wide adaptability, grow well both in fresh and in salt water, are resistant to oxygen deficiency and high content of organic substances in water $[7,8]$. Tilapia is able to multiply throughout the year. They reach mass in the first year of cultivation. Meat tilapia dense, non-fat, protein content close to trout meat, does not contain intermuscular bones.

Tilapia is heat-loving species. The boundaries of their normal vital activity lie within 22-350C (threshold $10-150$ and 38-420C). Tilapia well tolerates oxygen deficiency (optimal content $-5-7 \mathrm{mg} / \mathrm{l}$ ), resistant to high oxidation of water and acidic medium. Cultivation of commodity tilapia is carried out at a planting density of 450$500 \mathrm{ind} / \mathrm{m} 3$. The duration of the cultivation of this fish to the $250-300 \mathrm{~g}$ weight is $120-130$ days, the survival of fish is $85-90 \%$. Tilapias have high environmental plasticity. In brackish water with a concentration of $15-20 \%$ tilapia grows and multiplies better than fresh [4]. One of the most important foundations of the intensification of production during the cultivation of any species is rational feeding, it is based on the use of the highly effective feed $[5,6]$. Although for fish, based on a study of their nutritional needs for essential nutrients, amino acids, fatty acids and vitamins, starting and production feed are developed, the actual practice of fish farming shows that the problem of the fish feeding is far from being completely solved. Growing tilapia in artificial environment, such as setting a closed cycle of water supply, in the absence of natural food, high planting density, places special demands on the quality of the compound feed $[7,8]$.

At the first stage of work, works of foreign scientists were analyzed and tilapia needs in nutrient and biologically active substances were formed, as well as amino acid requirements, mineral requirements, water and fat soluble vitamins, which are essential to ensure the 
Table 1. Requirements of Tilapia in amino acids [12,16]

\begin{tabular}{||l||c||c||}
\hline \multicolumn{1}{|c||}{ \% Protein } & \multicolumn{2}{c||}{ Requirements } \\
\cline { 2 - 3 } & 1993 & 2011 \\
\hline \hline Arginin & 1.18 & 1.20 \\
\hline \hline Histidine & 0.48 & 1.00 \\
\hline \hline Isoleucine & 0.87 & 1.00 \\
\hline \hline Leucine & 0.95 & 1.90 \\
\hline \hline Lysine & 1.43 & 1.60 \\
\hline \hline Methionine & - & 0.70 \\
\hline \hline Methionine+Cystine & 0.90 & 1.00 \\
\hline \hline Phenylalanine & - & 1.10 \\
\hline \hline Phenylalanine+Tyrosine & 1.55 & 1.60 \\
\hline \hline Threonine & 1.05 & 1.10 \\
\hline \hline Tryptophan & 0.28 & 0.30 \\
\hline \hline Valin & 0.78 & 1.50 \\
\hline \hline
\end{tabular}

Table 2 Requirements of tilapia in minerals [12]

\begin{tabular}{|c|c|c|}
\hline$\%$ & \multicolumn{2}{|c|}{ Requirements } \\
\hline \multicolumn{3}{|c|}{ Macro elements, $\%$} \\
\hline Calcium & - & 0.70 \\
\hline Chlorine & - & 0.15 \\
\hline Magnesium & 0.06 & 0.06 \\
\hline Phosphorus & 0.50 & 0.40 \\
\hline Potassium & - & $0.2-.03$ \\
\hline Sodium & - & 0.15 \\
\hline \multicolumn{3}{|c|}{ "Microelements, mg/kg } \\
\hline Copper & - & 5 \\
\hline Iodine & - & - \\
\hline Iron & - & 85 \\
\hline Manganese & $\overline{\mathrm{R}}$ & 7 \\
\hline Selenium & - & - \\
\hline Zink & 20 & 20 \\
\hline
\end{tabular}

Table 3 - The needs of tilapia in the water and fat soluble vitamins [12]

\begin{tabular}{||l||c||c||}
\hline \multicolumn{1}{||c||}{$\begin{array}{c}\text { Name of vitamin } \\
\text { mg/kg dry matter }\end{array}$} & \multicolumn{2}{c||}{ Requirements } \\
\hline \hline Water-soluble vitamins & 1993 & 2011 \\
\hline \hline Thiamine & NT & NT \\
\hline \hline Riboflavin & 6 & 6 \\
\hline \hline B6 & NT & 15 \\
\hline \hline Pantothenic acid & 10 & 10 \\
\hline \hline Niacin & NT & 26 \\
\hline \hline Folyat & NT & 0.06 \\
\hline \hline Choline & NR & NR \\
\hline \hline Ascorbic acid C & NT & 1 \\
\hline \hline $\begin{array}{l}\text { Fat-soluble vitamins, } \\
\text { mg/kg }\end{array}$ & NT & 1.8 \\
\hline \hline Vitamin A & NT & 9 \\
\hline \hline Vitamin D & 50 & 60 \\
\hline \hline Vitamin E & NT & NT \\
\hline \hline Vitamin K & & \\
\hline \hline
\end{tabular}

optimal quality level of tilapia feed and improve the performance of the different fish age groups. The modern requirements of tilapia in in amino acids (table 1), minerals (table 2), the water and fat soluble vitamins (table 3) were analyzed $[9,10,11,12,13]$.

The physical properties of mixed feeds for tilapia (as for all fish feeds) have indicators as size, moisture content, durability, bulk weight, angle of repose, etc. To date, feeds for tilapia are produced in extruded and pelleted form. The length of the pellets for all numbers of groups should not exceed 1.5 diameters. The fragility of the pellets should be not more than $8 \%$, water resistance not less than 25 minutes [6, 14-16]. The size of the pellets (crumbles) of feed depends on the body weight of the fish.

The nutritional content of compound feeds for the tilapia indicates the crude moisture content, protein content, crude fat, crude ash, crude fiber, calcium, phosphorus, lysine, methionine and cysteine, some vitamins, the presence of metallomagnetic and harmful impurities, pest infestation [4-14]. For tilapia it is used sinning or floating feeds [10-14].

\section{Results and its discussion}

It was considered the current programs for feeding of tilapia (firms Cargill, Purina, Biomar, Coppens, MyAquaponics). They have represented the latest achievements of the science in the field of fish nutrition, practices and advanced technologies for the production of animal mixed feeds. The authors have analyzed the feeding programs for tilapia, on the basis of which the following conclusions can be drawn (Fig. 2, Table 4):

- the feed producers use tilapia feeding programs that differ in nutritional value of feed;

- - modern feeding programs mainly divide the tilapia breeding period into prestart, start, grower's and production (finisher's) (Fig. 2);

- or fish of the same age within the same manufacturer make feed, which differ in nutritional value,

- it was noticed the tendency to a decrease in the content of crude protein with an increase in the body weight of tilapia fish, which is similar for other fish species (Fig. 2).

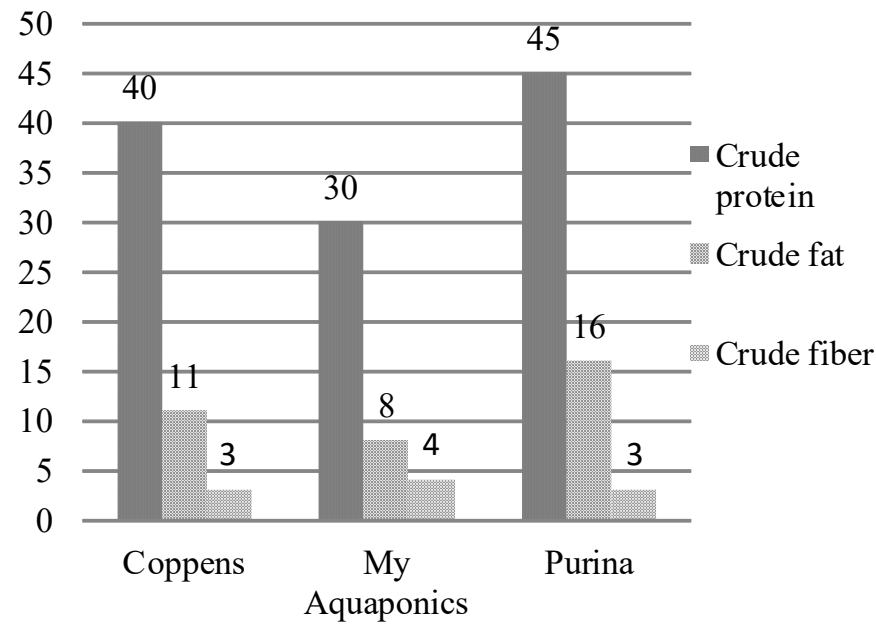

Fig. 2 - Nutrient content of tilapia feed recipes for growers of various manufacturers 
At the moment, feed for tilapia on the world market are represented by foreign manufacturers such as Cargill, Purina, Biomar, Coppens, MyAquaponics, which have achieve respect of the both foreign and domestic consumers and continue to be popular due to the highquality raw materials that are used and the latest technologies used.

The authors have reviewed the feeding programs of such foreign producers as Purina, Coppens, MyAquaponics (Fig. 2).

Based on the analysis of feeding programs and recommendations from foreign sources, we developed our own feeding program for tilapia, shown in Table 4, and compound feed recipes were calculated. For starter mixed feeds, the content of crude protein should be at least $45 \%$, crude fat at least $12 \%$, crude fiber not more than $1.5 \%$, gross energy not less than $18 \mathrm{MJ}$, crude ash not more than $8 \%$.

Table 4 - Nutritional value of mixed feeds according the feeding program for Tilapia fish

\begin{tabular}{||l||c|c||c||}
\hline \multicolumn{1}{|c||}{ Indicators } & \multicolumn{3}{c||}{ Period of growing } \\
\cline { 2 - 4 } & Starter & Grower & Finishing \\
\hline \hline Crude protein, \% & 45.0 & 40.0 & 30.0 \\
\hline \hline Crude fat, \% & 12.0 & 12.0 & 6.0 \\
\hline \hline Crude ash, \% & 8.0 & 7.0 & 7.0 \\
\hline \hline Crude fiber, \% & 1.5 & 3.0 & 5.0 \\
\hline \hline Lysine & 1.60 & 1.60 & 1.60 \\
\hline \hline Methionine & 0.70 & 0.70 & 0.70 \\
\hline \hline Vitamins: & & & \\
A, MO/ kg & 1.8 & 1.8 & 1.8 \\
D, MO/kg & 9.0 & 9.0 & 9.0 \\
E, mg/ kg & 50.0 & 50.0 & 50.0 \\
C, mg / kg & 20.0 & 20.0 & 20.0 \\
\hline \hline Gross energy, $\mathrm{mJ} / \mathrm{kg}$ & 18.0 & 17.8 & 17.1 \\
\hline \hline
\end{tabular}

\section{REFERENCES}

1. Albert, Tacon. Metian Global overview on the use of fish meal and fish oil in industrially compounded aquafeeds: Trends and future prospects. USA. J. Aquaculture. - 2008. - P. 146-158.

2. FAO. 2018. FAO Fisheries Department, Fishery Information, Data and Statistics Unit. FishStatJ, a tool for fishery statistics analysis, Release: 3.04.5, Universal Software for Fishery Statistical Time Series. Global aquaculture production: Quantity 1950-2016; Value 1950-2016; Global capture production: 1950-2016; 2018-03-16.

3. FAO (Food and Agriculture Organization of the United Nations). 2007. Fishstat Plus. FAO, Rome.

4. Popma, T. and Michael. M. (1999) Tilapia life history and biology. SRAC Publication No. 23. Pp. 1-5.

5. Yehorov B. V. Tekhnolohiya vyrobnytstva kombikormiv. - Odesa: Drukars'kyy dim, 2011. - $448 \mathrm{~s}$.

6. Yehorov B.V. Osoblyvosti vyrobnytstva kombikormiv dlya ryb/Yehorov B.V., Fihurs'ka L.V. / Khranenye y pererabotka zerna, №12, $\square$ S. 58-60.

7. Abdelghany, A. E., M. S. Ayyat and M. H. Ahmad. 2002. Appropriate timing of supplemental feeding for production of Nile tilapia, silver carp, and common carp in fertilized polyculture ponds. J. World Aquacult. Soc., 33: 307-315.

8. De Silva, S. S. 2007. Reducing feed costs through adoption of mixed feeding schedule practices in semi-intensive aquaculture. Int. Aqua Feed, 10(5): 18-22

9. Jauncey, K; Ross, B (1982). A guide to Tilapia Feeds and Feeding. Stirling (UK): Institute of Aquaculture, University of Stirling. p. 11.

10. Latest Facts for Fish and Shrimp Feed Formulations (NRC bulletin on Nutrient Requirements for Fish and Shrimp, John E. Halver, Ph.D., NAS, MTA School of Aquatic \& Fishery Sciences University of Washington, Seattle, WA. USA.

11. Manufacturing tilapia feed. A manual using local feedstuff resources for fish farming in American Samoa.- CTSA Publication, 156 ,- 42p.

12. Wilson, M. F., Luiz E. P., Margarida M. B., Pezzato A. C., and Vale'ria R. B. (2004) Use of ideal protein concept for precision formulation of amino acid levels in fish meal free diets for juvenile Nile tilapia (Oreochromis niloticus L.). Aquaculture Research 35:1110-1116.

13. Takeuchi T., Satoh S., and Watanabe W. (1983 a). Dietary lipids suitable for practical feed of Tilapia nilotica. . Bulletin of Japanese Society of Fisheries Sciences Fish. 49 (9): 1361-1365.

14. B Iegorov / The characteristic of compound feeds for Clarias Gariepinus // B. Iegorov, L. Fihurska, M. TerzI, O Ruhlenko.- Grain Products and Mixed Fodder's, 2019. P. 36-41.

15. Steffens, W. Principles of fish nutrition [Text] / W. Steffens. - England: Chichester, 1989. - 384 p.

16. Yehorov, B.V. Analiz tekhnolohichnykh sposobiv vyrobnytstva kombikormiv dlya ryb [Tekst] / B.V. Yehorov, L.V. Fihurs'ka // Zernovi produkty i kombikormy. -2012 . - № 1. - S. 35-42. 
Л.В. Фігурська, канд. техн. наук, доцент, кафедра технології комбікормів і біопалива, В.В. Тхоренко., студентка ОКР «Магістр», Факультет технології зерна і зернового бізнесу Одеська національна академія харчових технологій, м. Одеса, Україна

\title{
ХАРАКТЕРИСТИКА КОМБІКОРМІВ ДЛЯ ТИЛЯПІї
}

\begin{abstract}
Анотація
У статті зазначено, що відповідно до літературного огляду в аквакультурі прісноводних видів риб, які набувають постійно зростаючих об'ємів виробництва, лідирує тиляпія - 17\%, та короп - 15\%. Протягом майже 60 років тиляпія перейшла на 2-е місие у світовому виробнищтві риби, з перспективою зайняти перше місие в найближчі 2-3 роки і обігнати коропа за світовим виробництвом. Оскільки риба є багатим джерелом білків та незамінних амінокислот, вітамінів, поліненасичених жирних кислот, макро- і мікроелементів, вона є і важливою складовою раціону населення. М'ясо тиляпії щџільне, нежирне, за вмістом білка наближається до м'яса форелі, не містить міжм'язових кісток. Одним з пріоритетних напрямків розвитку рибництва в Україні є вирочування тиляпії. Обсяг споживання кормів у світі з кожним роком зростає, щุо пов'язано зі швидким зростанням попиту на тиляпію. В даний час українські бізнесмени зачікавлені у виробництві сома $i$ тиляпії. Найбільш відомими підприємствами, які вирощують иі племінні об'єкти, є ТОВ «Лорен Аквакультура» (Рівненська область), ТОВ «Аква Систем Органік» (Київська область), ТМ «Сом від Павлиш» (Кіровоградська область), ТМ «Перший міський Рибницький завод», «Хочу сома»(Київ). Саме тому виробництво збалансованих вітчизняних комбікормів для типяпї̈ є важливим завданням комбікормової промисловості України. Теоретичне дослідження було присвячено питанню виробництва комбікормів для тиляпії. Пожсивна цінність комбікормів для тиляпї залежить від етапу життєвого ииклу даного виду риб. Наведені світові лідери-виробники комбікормів для тиляпії, проведено аналіз поживної иінності комбікормів для даного виду риб за вмістом сирого протеїну у стартовий, ростовий та фінішний періоди виромування відповідно. Наведено вимоги до вмісту основних замінних та незамінних амінокислот, мінеральних речовин (мікро та мікроелементів), водота жиророзчинних вітамінів та обмеження до вмісту сирої клітковини. Проаналізовано програми годівлі тиляпії різних виробників та розроблено власну програму годівлі даного виду риб, що поділяє період вирощування тиляпї стартовий, ростовий та фінішний. Для стартових комбікормів для тиляпії вміст сирого білка повинно бути не менше $45 \%$, сирого жиру не менше 12\%, сирої клітковини не більше 1,5\%, обмінної енергії не менше 18 МДж, сирої золи не більше 8\%. Для комбікормів для тиляпія ростового періоду вміст сирого білка повинен складати не менше 40\%, сирого жиру не менше 12\%, сирогї клітковини не більше 3\%, обмінної енергії не менше 17 МДж, сирої золи не більше 9,5\%. Для фінішних комбікормів для тиляпії вміст сирого білка повинен бути не менше $30 \%$, сирого жиру не менше 6\%, сирої клітковини не більше 5\%, обмінної енергії не менше 17 МДж, сирої золи не більше 7\%, для комбікормів для тиляпія усіх періодів вирощування вміст лізину не менше 1,6\%, метіоніну - не менше 0,7\%.
\end{abstract}

Ключові слова: комбікорми для тиляпї, технологія виробництва комбікормів для тиляпії, вимоги до поживності комбікормів для тиляпії.

\section{ЛІТЕРАТУР}

1. Albert, Tacon. Metian Global overview on the use of fish meal and fish oil in industrially compounded aquafeeds: Trends and future prospects. USA. J. Aquaculture. - 2008. - P. 146-158.

2. FAO. 2018. FAO Fisheries Department, Fishery Information, Data and Statistics Unit. FishStatJ, a tool for fishery statistics analysis, Release: 3.04.5, Universal Software for Fishery Statistical Time Series. Global aquaculture production: Quantity 1950-2016; Value 1950-2016; Global capture production: 1950-2016; 2018-03-16.

3. FAO (Food and Agriculture Organization of the United Nations). 2007. Fishstat Plus. FAO, Rome.

4. Popma, T. and Michael. M. (1999) Tilapia life history and biology. SRAC Publication No. 23. Pp. 1-5.

5. Yehorov B. V. Tekhnolohiya vyrobnytstva kombikormiv. - Odesa: Drukars'kyy dim, 2011. - 448 s.

6. Yehorov B.V. Osoblyvosti vyrobnytstva kombikormiv dlya ryb/ Yehorov B.V., Fihurs'ka L.V. / Khranenye y pererabotka zerna, №12, $\square$ S. $58-60$

7. Abdelghany, A. E., M. S. Ayyat and M. H. Ahmad. 2002. Appropriate timing of supplemental feeding for production of Nile tilapia, silver carp, and common carp in fertilized polyculture ponds. J. World Aquacult. Soc., 33: 307-315.

8. De Silva, S. S. 2007. Reducing feed costs through adoption of mixed feeding schedule practices in semi-intensive aquaculture. Int. Aqua Feed, 10(5): 18-22

9. Jauncey, K; Ross, B (1982). A guide to Tilapia Feeds and Feeding. Stirling (UK): Institute of Aquaculture, University of Stirling. p. 11.

10. Latest Facts for Fish and Shrimp Feed Formulations (NRC bulletin on Nutrient Requirements for Fish and Shrimp, John E. Halver, Ph.D., NAS, MTA School of Aquatic \& Fishery Sciences University of Washington, Seattle, WA. USA.

11. Manufacturing tilapia feed. A manual using local feedstuff resources for fish farming in American Samoa.- CTSA Publication, 156,- 42 $p$.

12. Wilson, M. F., Luiz E. P., Margarida M. B., Pezzato A. C., and Vale'ria R. B. (2004) Use of ideal protein concept for precision formulation of amino acid levels in fish meal free diets for juvenile Nile tilapia (Oreochromis niloticus L.). Aquaculture Research 35:1110-1116.

13. Takeuchi T., Satoh S., and Watanabe W. (1983 a). Dietary lipids suitable for practical feed of Tilapia nilotica. . Bulletin of Japanese Society of Fisheries Sciences Fish. 49 (9): 1361-1365.

14. B Iegorov / The characteristic of compound feeds for Clarias Gariepinus // B. Iegorov, L. Fihurska, M. TerzI, O Ruhlenko.- Grain Products and Mixed Fodder's, 2019. P. 36-41.

15. Steffens, W. Principles of fish nutrition [Text] / W. Steffens. - England: Chichester, 1989. - 384 p

16. Yehorov, B.V. Analiz tekhnolohichnykh sposobiv vyrobnytstva kombikormiv dlya ryb [Tekst] / B.V. Yehorov, L.V. Fihurs'ka // Zernovi produkty i kombikormy. - 2012. - № 1. - S. 35-42. 